\title{
COMPARISON OF TWO PARASITOLOGICAL TECHNIQUES FOR THE DIAGNOSIS OF INTESTINAL PARASITES IN A POPULATION OF IBERIAN IBEX (Capra pyrenaica SCHINZ, 1838) IN THE SIERRA DE GUADARRAMA NATIONAL PARK (SPAIN)
}

(Comparação de duas técnicas parasitológicas para o diagnóstico de parasitas intestinais numa população de cabra-montês (Capra pyrenaica Schinz, 1838) no

Parque Nacional de Sierra de Guadarrama - Espanha)

Benito Muñoz Araújo ${ }^{1}$, Zacarias Rosalina João da Silva ${ }^{2}$, Pablo Refoyo Román ${ }^{1}$, Cristina Olmedo Salinas ${ }^{1}$

\footnotetext{
${ }^{1}$ Universidad Complutense de Madrid, Facultad de Ciências Biológicas, Departamento de Biodiversidad, Ecología y Evolución, Madrid, España, ${ }^{2}$ Universidad Federal de Juiz de Fora, Laboratório de Protozoología, Programa de Posgrado en Biodiversidad y Conservación de la Naturaleza, Juiz de Fora, Minas Gerais, Brasil
}

Corresponding author: titomu@ucm.es

ABSTRACT: Twenty samples of Iberian ibex collected in October 2014 in Sierra de Guadarrama National Park (Spain) were analyzed to evaluate detectability of intestinal parasites by two concentration techniques: Ritchie (1948) and Anécimo et al. (2012) and also to analyze and compare the parasite catalogue of each technique. There has been a decrease in the diversity of species found and an increase in prevalence data with respect to previous studies carried out in the same area, possibly due to the increase in Iberian ibex density in the area. A nematode species (Nematodirus filicollis) that has not previously been found in the population under study and which typically parasites cattle, has also been identified. This suggests an exchange of parasites between wild ungulates population and domestic livestock in this area. There were no significant differences between the results obtained by the two techniques used so that, the improvement in the working conditions of the analysts that involves the use of the Anécimo technique by not using hazardous solvents to health, can serve as a guideline to change the protocol of action.

Keywords: Detectability; technique concentration stool; parasites.

RESUMO: Vinte amostras de cabra de montanha analisada neste artigo, foi recolhida em outubro de 2014, no Parque Nacional da Serra de Guadarrama na Espanha. A análise visou primeiro, avaliar a detetabilidade de parasitas intestinais com recurso duas técnicas de concentração, Ritchie (1948) e Anécimo et al. (2012), segundo, comparar o catálogo de parasitas para cada técnica. Os resultados da nossa análise mostram, que, em relação aos estudos anteriores realizados na mesma área: houve diminuição da diversidade de espécies, um aumento de dados de prevalência devido ao aumento da densidade de ibex na área, identificamos uma nova espécie de nemátodo (Nematodirus filicollis) cujos parasitas são tipicamente bovinos. Este último resultado, sugere que existe uma troca de parasitas entre a população de ungulados selvagens e o gado doméstico da área.

Quanto a utilização de duas técnicas de concentração, os resultados não mostram diferenças significativas entre os obtidos tanto pela técnica de Ritchie (1948) como pela técnica de Anécimo et al. (2012). Por causa disso, defendemos que, para a 
Comparison of two parasitological techniques for the diagnosis of intestinal parasites in a population of 32 Iberian ibex (Capra pyrenaica Schinz, 1838) in the Sierra de Guadarrama National Park (Spain)

melhoria de condições de trabalho de técnicos implica a utilização da metodologia proposta por Anécimo et al. (2012), por não utilizar solventes perigosos à saúde. Esta proposta pode servir de guia para alteração do protocolo de ação.

Palavras-chave: Detetabilidade; Técnica de concentração fezes; Parasitas. 


\section{INTRODUCTION}

The study of species that parasitize wildlife has greatly advanced in the last decade, progressively increasing the interest that parasites play in biodiversity and ecosystem dynamics (Hatcher and Dunn, 2011). The knowledge of the negative effect of parasites on livestock production, wildlife conservation and human health has increased their interest and the number of studies. (Barasona, 2015)

In the case of ruminants, abundance of gastrointestinal parasites can have great importance in their population dynamics (Díez-Baños and Hidalgo-Argüello, 2006); parasites can decrease reproductive success, either through a direct effect on fertility (Body et al., 2011) or through a negative impact on growth and body condition (Joly and Messier, 2005). This effect may be the result of subtle interactions between the host, the parasites and the environment and therefore, may be subject to factors such as the availability of food, infections by other pathogens, etc. (Smith et al., 2005).

Several studies indicate the influence of parasites on the reproductive success of different wild mammals without the need to produce apparent pathogenicity (Marzal et al., 2005; Tompkins et al., 2011); they can also directly or indirectly influence the dynamics of their populations affecting their vulnerability, predation or competition for trophic resources (Hernández et al., 2001; Wisnivesky, 2003; Hudson et al., 2006; Audesirk et al., 2008; Tompkins et al., 2011). These effects will be conditioned by the general condition of the animal (Wisnivesky, 2003), age, type of feeding, way of life, climate and seasonality (Quiroz, 2005). Parasitic infections in Iberian ibex are frequent, serious and well documented, with about a hundred parasites described. (Refoyo et al., 2016).
The main problem when performing a parasitological study is the manipulation of the host, especially when dealing with large mammals such as ungulates. Although the coprological analysis has become a very effective technique to obtain information on parasites that affect wildlife without resorting to invasive techniques (Balmori et al., 2000; Alasaad et al., 2008; BeltránSaavedra et al., 2009), it limits its study to the forms that live in the intestine or that eliminate their infectious forms through it (Cordero del Campillo and Rojo, 2000). In addition, the study of the coprological samples allows in the obtaining of complementary data of the studied population such as taxonomically identify the diets, measure hormones to study the relationship with the reproductive behaviour or establish the different trophic interrelationships in an ecosystem (Beltrán-Saavedra et al., 2009).

To face a parasitic coprological analysis there is a series of techniques that allows the identification of different forms of dispersion of parasitic species such as trophozoites, cysts and oocysts in the case of protozoa and eggs and larvae in the case of helminths (Cordero del Campillo and Rojo, 2000). In order to concentrate the different forms that can appear in a sample, it is necessary to use different enrichment techniques such as sedimentation, flotation or combining both, to increase the sensitivity of the observation when the number of parasitic forms is low and there is absence in the direct examination of the sample (Salvatella and Eirale, 1996). Among the most used techniques of sedimentation is the Ritchie technique and among the flotation techniques are Willis (saturated sodium chloride solution) or Faust (zinc sulfate solution) (Salvatella and Eirale, 1996; Cordero del Campillo and Rojo, 2000). 
There are several works that use these and other techniques of concentration in different groups of animals. In ungulates, the Ritchie technique or any of its modifications (Teleman technique, modified Ritchie, miniParasep, etc.) and the Willis technique, obtain good results (Alasaad et al., 2008; Refoyo, 2012). Different studies have also been carried out comparing the detectability and effectiveness of the different techniques, both sedimentation versus flotation and between the different sedimentation techniques (McNabb et al., 1985; Beltrán et al., 2003; Del Coco et al., 2008; Tenorio-Abreu et al., 2013; Barba, 2015; Barbosa et al., 2016).

Nowadays, modifications of coprological techniques are increasing in order to avoid the use of chemical solvents and replacing them with neutral solvents and, therefore, reducing the risk of exposure of health professionals and avoiding the generation of potentially polluting residues. In those techniques, the ether is replaced by different solvents, the formaldehyde by distilled water or ethyl alcohol in different concentrations (Del Coco et al., 2008; Anécimo et al., 2012; Tenorio-Abreu et al., 2013). All techniques show very good results in human samples but have not been used in herbivorous animals, except the MiniParasep commercial kit which uses formaldehyde and neutral soap in a capsule with a filter with a pore size of $425 \mu \mathrm{m}$ and which, in the case of the Iberian ibex, has not given satisfactory results in the study of parasitic load compared to the Ritchie technique but adequate in diversity studies (Barba, 2015).

In this work, the Ritchie technique has been compared with the modification proposed by Anécimo et al. (2012) that replaces formaldehyde by hot distilled water and ether by neutral soap in a population of Iberian ibex in a protected natural area.
Our aim is to compare the detectability and efficacy to study the parasitic load between the Ritchie technique (Ritchie,1948) and the modified technique proposed by Anécimo et al. (2012) in order to assess the risk of exposure to chemical solvents by analysts in the event that no significant differences were observed between the two techniques in a population of Iberian ibex of the Sierra de Guadarrama National Park (Spain).

\section{MATERIALS AND METHODS}

In October 2014, samples of fresh faeces were collected from 20 adult individuals of a population of Iberian ibex from the Sierra de Guadarrama National Park (Spain) at an altitude of 2000 meters (Figure 1). This national park has an area of 33,960 ha and it is located in the centre of the Iberian Peninsula, in the eastern part of the Central System mountains.

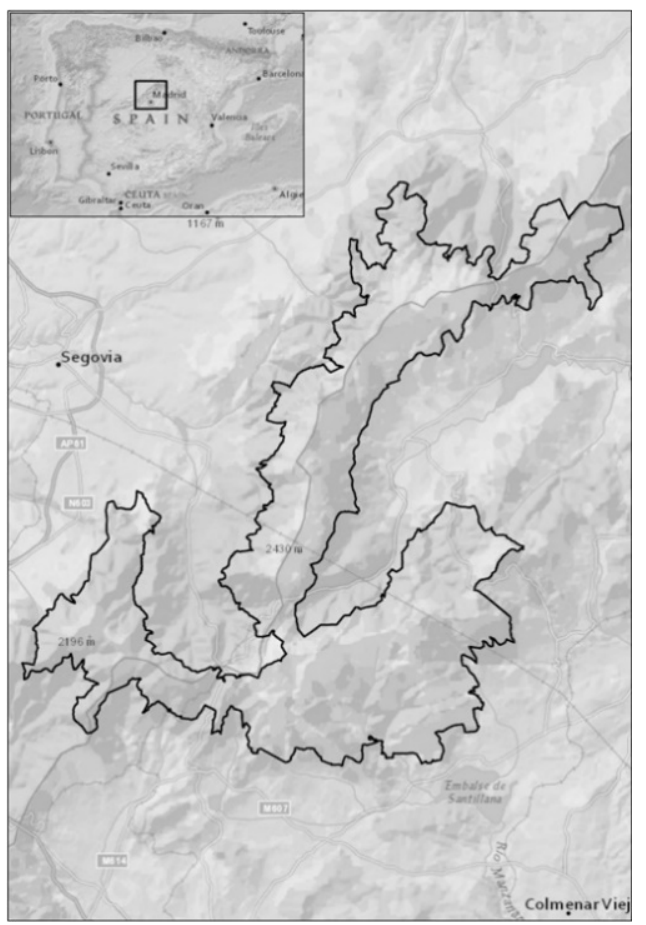

Figure 1. Study area.

Faeces samples were collected directly from the soil to avoid the use of 
invasive techniques that cause stress in the population. Sampling was done at dawn by locating groups of mountain goats in the study area. Once the groups were located, we wait for them to move to collect fresh faeces from the animals ensuring a minimum distance between faeces to be able to individualize the samples, as indicated by Acevedo et al. (2005) and Acevedo et al. (2011). Therefore, only one sample was selected from each group (20 groups), thus avoiding possible pseudoreplications.

The samples were collected in independent plastic bags and properly labeled with the sample number. They were transported fresh and in the laboratory were sieved using distilled water and kept in a refrigerator at $4^{\circ} \mathrm{C}$ for further processing, according to Carvalho et al. (2012). They were kept at room temperature for one week in a solution of sodium acetate buffer $\mathrm{pH} 5$ to allow the oocysts sporulation (Ayres and Mara, 1997).

The samples were sieved using $1 \mathrm{~mm}$ mesh of light in order to separate the faecal remains from other possible elements (plants, minerals, etc.) that could have been mixed with the faeces (Fernández de Mera, 2007). Next, part of the sample was centrifuged with saline solution at $2500 \mathrm{rpm}$ for one minute to remove the sodium acetate buffer $\mathrm{pH} 5$, discarding the supernatant and the processed solution was poured into tubes containing $10 \mathrm{~mL}$ of saline solution and the centrifugation was repeated for one minute at $2000 \mathrm{rpm}$ until obtaining translucent supernatants.

Thus, from each of the obtained samples, $3 \mathrm{~g}$ were processed following the Ritchie's concentration technique by sedimentation (Salvatella and Eirale, 1996) and other $3 \mathrm{~g}$ following the protocol of the Ritchie modified technique by Anécimo et al. (2012). After processing all samples by each technique, $100 \mu \mathrm{L}$ was taken with a $1 \mathrm{~mL}$ pipette to make a microscopic preparation adding a drop of iodine solution and observing it under an optical microscope. The search for parasitic forms was carried out using the objective of 10x and 40x and was measured (major axis and minor axis) and also photographed using a micrometric eyepiece with the objective of 40x. Protozoa and helminths are identified by morphometric analysis according to Kaufmann (1996), Cordero del Campillo and Rojo (2000), Quiroz (2005) and Refoyo (2012). But this type of analysis is problematic due to the existence of cryptic and polymorphic species (Indre et al., 2010; Yang et al., 2014). However, both larvae and adults of helminths have taxonomic characteristics that allow a more precise determination (Van Wyk et al., 2003; Van Wyk and Mayhew, 2013). Nevertheless, morphometric data are compared with those obtained by other authors in the study area for the same host (Refoyo, 2012; Barba, 2015; Refoyo et al., 2016).

A statistical analysis was carried out to compare the detectability of the two techniques used considering values of $P<0,05$ as significant. In this sense, a nonparametric test to determine the significance of the two techniques was used, the Mann-Whitney test, as well as the Kruskal-Wallis test to confirm the significance of the variables used in the two techniques. Statistical analyses were performed using STATISTICA version 7.0 (StatSoft Inc., Tulsa, Oklahoma, USA).

\section{RESULTS}

Coccidia were detected in 17 of the 20 analyzed samples (85\%) while nematodes were detected in 16 of the 20 samples $(80 \%)$ (Table 1$)$. However, prevalence slightly varies when we observe independently each technique. In the Ritchie technique, coccidian 
appears in $75 \%$ of the samples and in the Anécimo technique increases up to $80 \%$. Considering the group of nematodes, in the Ritchie technique prevalence was $60 \%$ compared to $65 \%$ in the Anécimo technique (Table 1). For all that, the two sedimentation techniques can be used to search and identify coccidia and nematodes although the Anécimo technique seems to be more effective for both groups.

Table 1. Prevalence data for each of the two techniques used for the two groups of parasites observed by sample.

\begin{tabular}{ccccc}
\hline \multirow{2}{*}{ SAMPLE } & \multicolumn{2}{c}{ Coccidia } & \multicolumn{2}{c}{ Nematodes } \\
\cline { 2 - 5 } & $\mathbf{R}^{\mathbf{1}}$ & $\mathbf{A}^{\mathbf{2}}$ & $\mathbf{R}^{\mathbf{1}}$ & $\mathbf{A}^{\mathbf{2}}$ \\
\hline $\mathbf{1}$ & 0 & 1 & 0 & 1 \\
$\mathbf{2}$ & 1 & 1 & 1 & 1 \\
$\mathbf{3}$ & 1 & 1 & 0 & 1 \\
$\mathbf{4}$ & 1 & 1 & 1 & 0 \\
$\mathbf{5}$ & 1 & 0 & 1 & 1 \\
$\mathbf{6}$ & 0 & 0 & 0 & 0 \\
$\mathbf{7}$ & 1 & 1 & 1 & 0 \\
$\mathbf{8}$ & 1 & 1 & 0 & 1 \\
$\mathbf{9}$ & 0 & 0 & 0 & 0 \\
$\mathbf{1 0}$ & 0 & 0 & 0 & 0 \\
$\mathbf{1 1}$ & 1 & 1 & 1 & 1 \\
$\mathbf{1 2}$ & 1 & 1 & 1 & 1 \\
$\mathbf{1 3}$ & 0 & 1 & 1 & 1 \\
$\mathbf{1 4}$ & 1 & 1 & 1 & 1 \\
$\mathbf{1 5}$ & 1 & 1 & 1 & 1 \\
$\mathbf{1 6}$ & 1 & 1 & 1 & 0 \\
$\mathbf{1 7}$ & 1 & 1 & 0 & 1 \\
$\mathbf{1 8}$ & 1 & 1 & 1 & 1 \\
$\mathbf{1 9}$ & 1 & 1 & 1 & 1 \\
$\mathbf{2 0}$ & 1 & 1 & 0 & 0 \\
\hline Total & 15 & 16 & 12 & 13 \\
\hline PREVALENCE (\%) & $\mathbf{7 5}$ & $\mathbf{8 0}$ & $\mathbf{6 0}$ & $\mathbf{6 5}$ \\
\hline${ }^{1}$ Ritchie technique ${ }^{2}$ Anécimo technique & & & \\
& & & & \\
\hline & & & 1 & \\
\hline
\end{tabular}

Having into account these values, we see that the most prevalent coccidium species in the two techniques has been Eimeria christenseni with 55\% in the Ritchie and $60 \%$ in the Anécimo, followed by the $E$. arloingi-cylindrica complexes and E. caprina-caprovina (40\% in both techniques for the first case and $35 \%$ and $55 \%$ for Ritchie and Anécimo techniques for the second, respectively) (Table 2). Due to its scarce morphological differences and to reduce the risk of error in the identification of coccidia, we have decided to group the species into complexes because of the great difficulty of identifying each species in an individualized way.

If we now analyze the obtained data by each technique separately, we observe that there are hardly any differences except for $E$. ninakohlyakimovae which has only been detected by the Anécimo technique and with a rather lower prevalence compared with the rest of the species. This may be since the detectability is improved with 
the Anécimo technique because the preparations are clearer because of the high dispersion of the organic matter fragments thanks to the use of the detergent.

Table 2. Prevalence data for each of the two techniques used by sample.

\begin{tabular}{|c|c|c|c|c|c|c|c|c|c|c|c|c|c|c|c|c|}
\hline \multirow{3}{*}{ SAMPLE } & \multicolumn{8}{|c|}{ Coccidia } & \multicolumn{8}{|c|}{ Nematoda } \\
\hline & \multicolumn{2}{|c|}{$\mathrm{Ech}^{3}$} & \multicolumn{2}{|c|}{ Ear-cy ${ }^{4}$} & \multicolumn{2}{|c|}{ Eca-co ${ }^{5}$} & \multicolumn{2}{|c|}{ Eni $^{6}$} & \multicolumn{2}{|c|}{$\mathrm{Nsp}^{7}$} & \multicolumn{2}{|c|}{$\mathrm{Nfi}^{8}$} & \multicolumn{2}{|c|}{$\mathrm{Mca}^{9}$} & \multicolumn{2}{|c|}{ Dvi ${ }^{10}$} \\
\hline & $\mathbf{R}^{1}$ & $A^{2}$ & $\mathbf{R}^{1}$ & $A^{2}$ & $\mathbf{R}^{1}$ & $A^{2}$ & $\mathbf{R}^{1}$ & $A^{2}$ & $\mathbf{R}^{1}$ & $A^{2}$ & $\mathbf{R}^{1}$ & $A^{2}$ & $\mathbf{R}^{1}$ & $A^{2}$ & $\mathbf{R}^{1}$ & $A^{2}$ \\
\hline 1 & & 1 & & & & & & & & & & 1 & & & & \\
\hline 2 & 1 & 1 & & & & & & & & 1 & & & 1 & & & \\
\hline 3 & 1 & & 1 & 1 & 1 & 1 & & & & & & 1 & & 1 & & \\
\hline 4 & 1 & & 1 & 1 & & 1 & & 1 & 1 & & & & 1 & & & \\
\hline 5 & & & 1 & & 1 & & & & 1 & 1 & 1 & 1 & 1 & 1 & & \\
\hline \multicolumn{17}{|l|}{6} \\
\hline 7 & 1 & 1 & 1 & & & 1 & & & & & & & & & 1 & \\
\hline 8 & 1 & 1 & & & & 1 & & & & 1 & & & & 1 & & \\
\hline \multicolumn{17}{|l|}{9} \\
\hline \multicolumn{17}{|l|}{10} \\
\hline 11 & & & & 1 & 1 & & & 1 & 1 & & 1 & & 1 & 1 & & \\
\hline 12 & & & 1 & & 1 & 1 & & & 1 & 1 & & & 1 & 1 & & \\
\hline 13 & & 1 & & & & & & & & 1 & & 1 & 1 & & & \\
\hline 14 & 1 & 1 & 1 & 1 & 1 & 1 & & 1 & 1 & & 1 & & 1 & 1 & & \\
\hline 15 & 1 & 1 & & 1 & & 1 & & 1 & & & & & 1 & & & 1 \\
\hline 16 & 1 & 1 & & 1 & 1 & 1 & & & 1 & & & & 1 & & & \\
\hline 17 & 1 & 1 & 1 & & 1 & 1 & & & & 1 & & & & 1 & & \\
\hline 18 & 1 & 1 & & 1 & & 1 & & & & 1 & & & 1 & 1 & & \\
\hline 19 & 1 & 1 & & 1 & & 1 & & 1 & 1 & 1 & & 1 & 1 & 1 & & \\
\hline 20 & & 1 & 1 & & & & & & & & & & & & & \\
\hline Total & 11 & 12 & 8 & 8 & 7 & 11 & 0 & 5 & 7 & 8 & 3 & 5 & 11 & 9 & 1 & 1 \\
\hline PREVALENCE (\%) & 55 & 60 & 40 & 40 & 35 & 55 & 0 & 25 & 35 & 40 & 15 & 25 & 55 & 45 & 5 & 5 \\
\hline
\end{tabular}

${ }^{1}$ Ritchie technique; ${ }^{2}$ Anécimo technique; ${ }^{3}$ Eimeria christenseni; ${ }^{4} E$. arloingi-cylindrica complex; ${ }^{5} E$. caprinacaprovina complex; ${ }^{6} \mathrm{E}$. ninakohlyakimovae; ${ }^{7}$ Nematodirus spathiger; ${ }^{8} \mathrm{~N}$. filicollis; ${ }^{9}$ Muellerius capillaris; ${ }^{10}$ Dictyocaulus viviparus.

In addition, the oocysts of this species are small, so it is easy for them to be concealed by the remains of organic matter and, therefore, it is much more difficult to detect them using the Ritchie technique. When analyzing whether there are differences in the detectability of both techniques with Mann-Whitney test for: number of parasites detected $(\mathrm{U}(1-120)=6947.00$; $\mathrm{P}=0.638)$, number of species $(\mathrm{U}(1-120)=$ 7076.50; $P=0.8013)$ and by groups found for both coccidia $(U(1-120)=$ 6798.50; $\mathrm{P}=0.4553)$ and nematodes $(U(1-120)=6852.00 ; \quad P=0.5175), \quad$ in general and by species (Coccidian U(1$120)=6866.50 ; P=0.5351$ ) (Nematodes $U(1-120)=6868.00 ; \quad P=0.5369), \quad$ no significant differences were detected $(P<0,05)$ between the two techniques for none of the variables analyzed.

Considering each of the variables analyzed independently (number of parasites and diversity of parasites both globally and by groups), no significant differences were detected (Box-Plot) for each technique (Figures 2, 3 and 4).

In relation to the box plots exposed above, for all the analyzed variables (global parasites, coccidia and 
nematodes), it seems that both techniques (Ritchie and Anécimo) have the same sensitivity in relation to the reliability in detecting intestinal parasites in the samples of Iberian ibex faeces observed in this work.

When comparing the two techniques with respect to the presence of artifacts (remains of organic matter) in the preparations studied under the
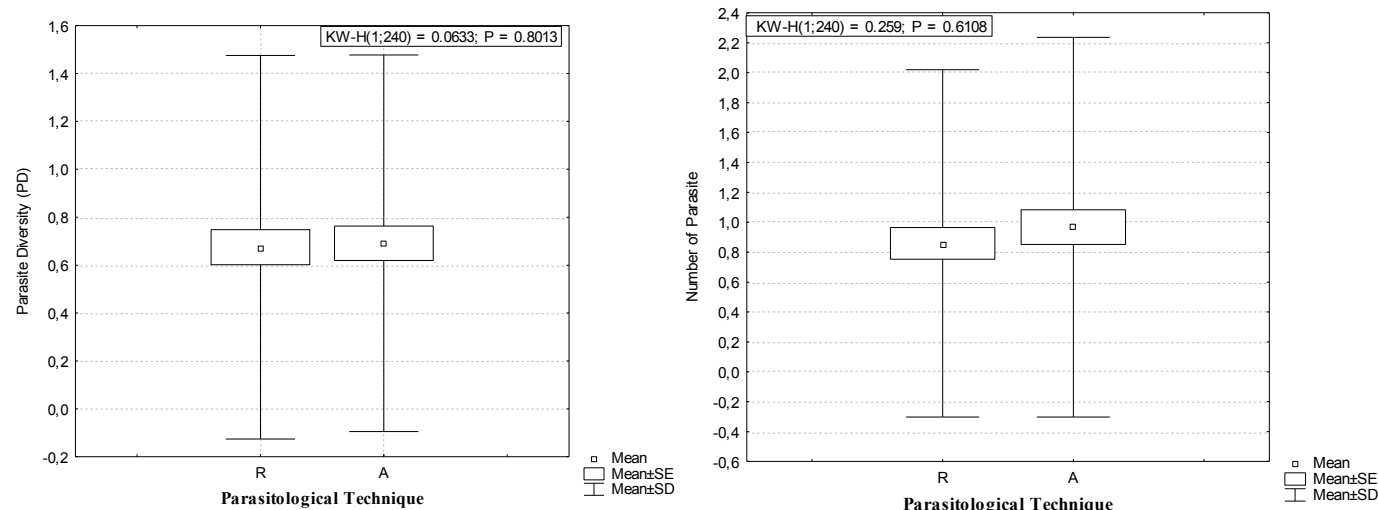

Figure 2. Diversity of parasites by sample. Left number of species and right number of individuals. R: Ritchie technique; A: Anécimo technique. $\mathrm{KW}-\mathrm{H}$ : Kruskal-Wallis test.
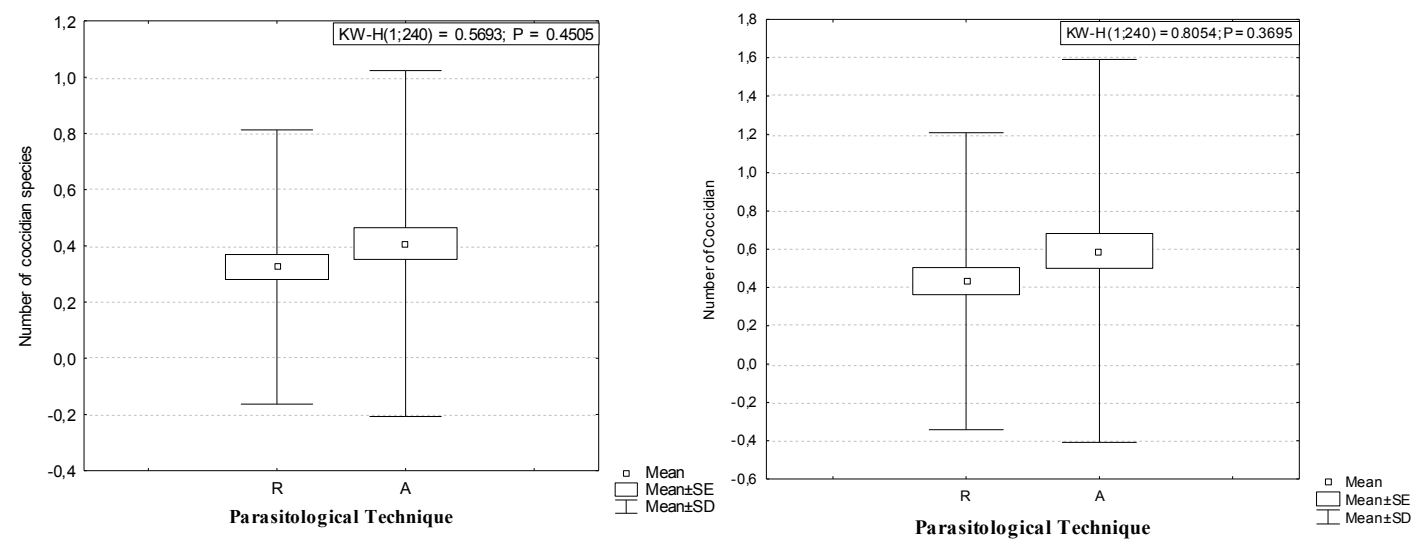

Figure 3. Diversity of number of Coccidia by sample. Left number of species and right number of individuals. R: Ritchie technique; A: Anécimo technique. KW-H: Kruskal-Wallis test.
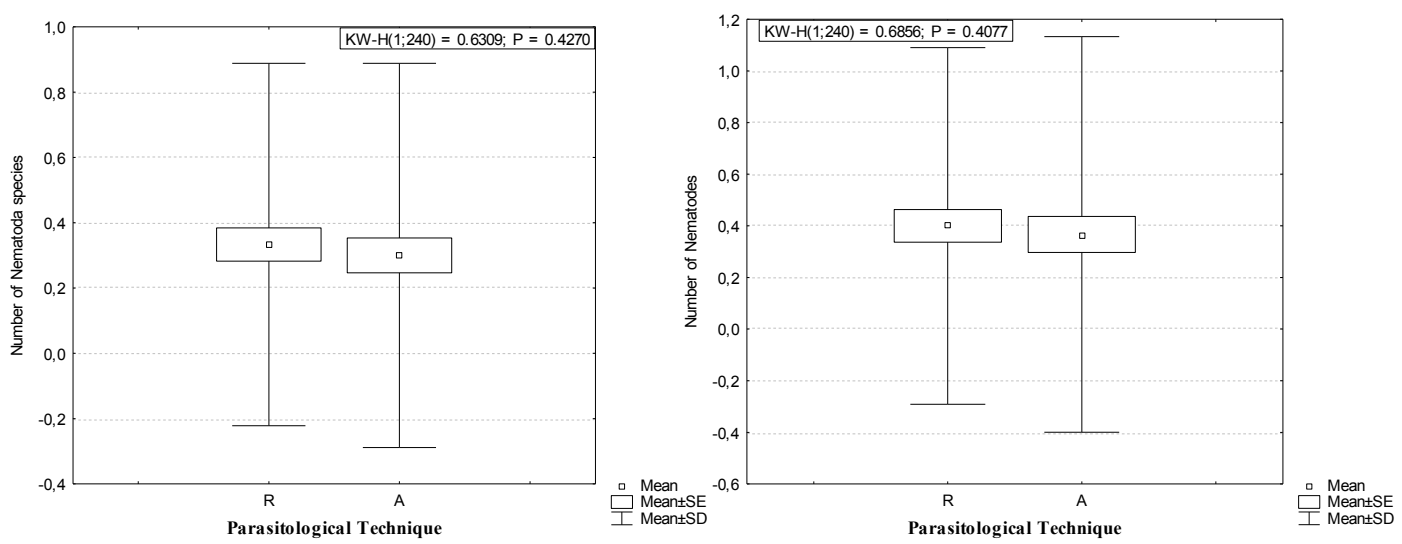

Figure 4. Diversity of nematodes by sample. Left number of species and right number of individuals. R: Ritchie technique; A: Anécimo technique. $\mathrm{KW}-\mathrm{H}$ : Kruskal-Wallis test. 

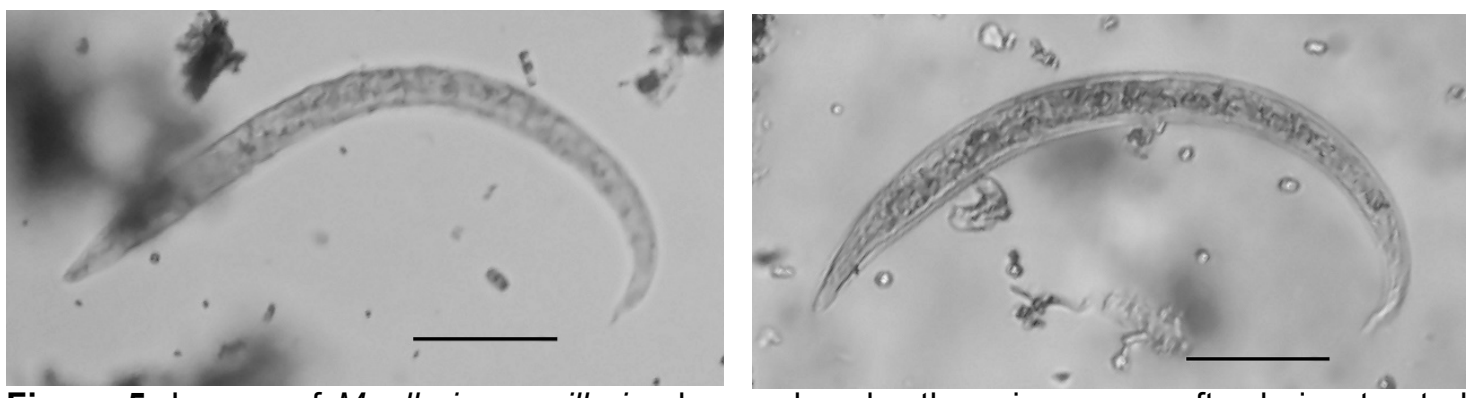

Figure 5. Larvae of Muellerius capillaris observed under the microscope after being treated with the Ritchie (left) and Anécimo (right) techniques. Scale bar: $50 \mu \mathrm{m}$.
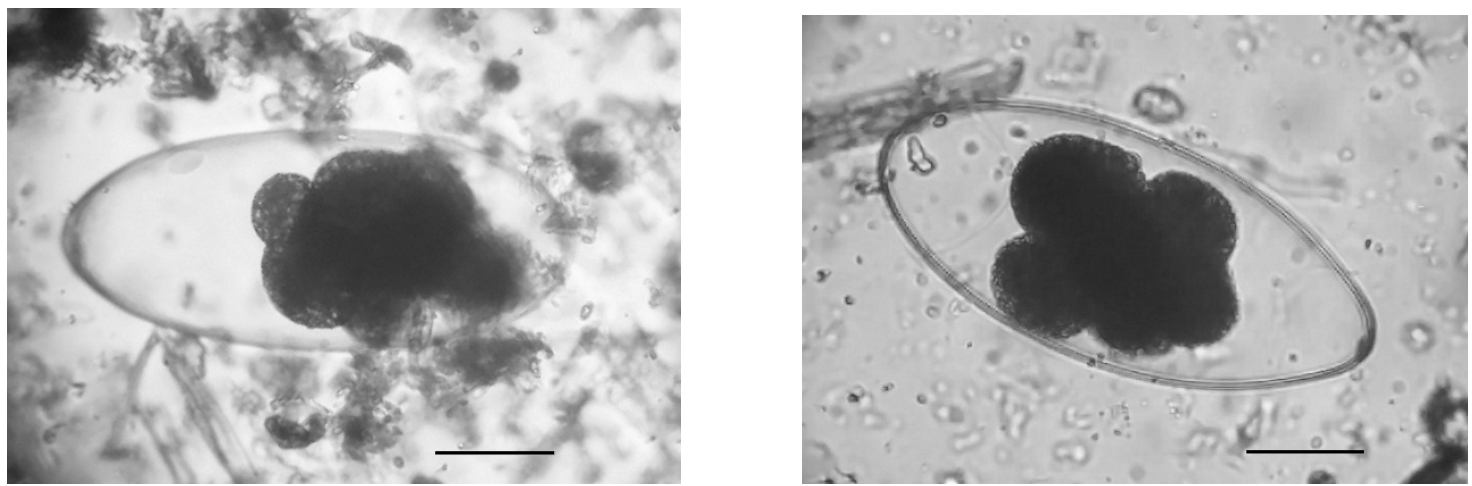

Figure 6. Nematodirus spathiger eggs observed under a microscope after being treated with the Ritchie (left) and Anécimo (right) techniques. Scale bar: $50 \mu \mathrm{m}$.
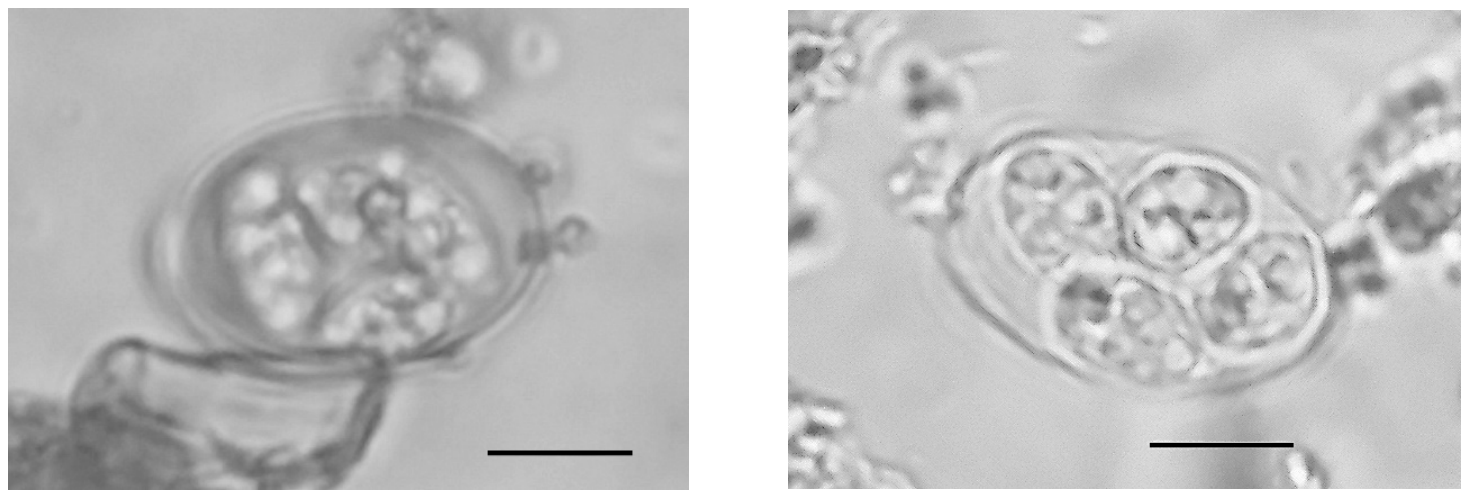

Figure 7. Oocysts of the Eimeria caprina-caprovina complex observed under the microscope after being treated with the Ritchie (left) and Anécimo (right) techniques. Scale bar: $10 \mu \mathrm{m}$.

\section{DISCUSSION}

Coprological studies to identify the parasitosis that affect animals provide reliable data of both biological and sanitary interest. This methodology allows the observation of the first stages of the development of parasites, eggs, oocysts and larvae of the digestive and respiratory system (Balmori et al., 2000) and the use of concentration techniques is essential to increase the detectability of organisms, especially in samples where abundance is low (Saez et al., 2012).

Regarding coccidia, the Iberian ibex is parasitized fundamentally with the genus Eimeria, its prevalence in the studied populations in Spain oscillates between $43 \%$ in Salamanca (Ramajo et al., 2007) and 74\% in Andalucia (Pérez Jiménez, 2005), south of Spain. In previous studies carried out in the study area, prevalence of $83.3 \%$ has been obtained (Barba, 2015). Our results agree with these data since the 
prevalence of this group of protozoa oscillate between $75 \%$ and $80 \%$ according to the method used for the analysis.

The species of coccidia located in this study match with those cited for wild goat by Alados and Escós (2012), although we have not found Eimeria hirci, a typical goat species that has not been previously mentioned in the study area (Refoyo, 2012; Barba, 2015). This may be due to the low prevalence reported in this host (Ruiz et al., 2006). However, we do find Eimeria cylindrica, a typical species of cattle (Cordero del Campillo and Rojo, 2000), abundant in the area and which has also appeared in the previous works (Refoyo, 2012; Barba, 2015).

Species with the highest prevalence data in this study has been Eimeria christenseni with values ranging between $55 \%$ and $60 \%$, very high values when compared with those obtained by Refoyo (2012) which place it at $25 \%$ and those of Barba (2015) that oscillate between $10 \%$ and $18 \%$, according to the technique used for their detection. In our study, prevalence data for nematodes ranging from $60 \%$ to $65 \%$, very high values when compared with those obtained by Barba (2015) with $34.4 \%$ but somewhat low for those found by Refoyo (2012) that reached $80 \%$. However, we have found a very low diversity since only 4 species have appeared unlike these authors detect 11 and 13 species, respectively.

The difference in results may be due to differences in the methodology followed (Refoyo, 2012; Barba, 2015). Refoyo (2012) conducts an annual follow-up study of the population taking samples in spring, summer and autumn, giving an average prevalence figure throughout the year. Barba (2015) carries out a sampling campaign in spring while we have done this work in the autumn season. This difference in the sampling campaigns affects the results obtained since the behaviour of the Iberian ibex population varies considerably throughout the year with small groups of animals being observed in the spring compared to the large herds observed in the fall, which could increase the risk of infection of animals.

As for Nematodirus spathiger, Barba (2015) obtains 1\% prevalence while Refoyo (2012) does it in $15 \%$ of the samples. In this study we obtain higher data, reaching $35-40 \%$. In addition, we have found Nematodirus filicollis with a prevalence ranging between $15-25 \%$ that had not been previously detected in the population under study; this species is common in cattle and other ruminants, so it is not uncommon to expect its occurrence in the Iberian ibex population with which it has a close relationship.

High prevalence data may be due to the strong increase of the ibex population in the study area which has gone from 6.57 ind. $/ \mathrm{km}^{2}$ in 1992 to $44.82 \mathrm{ind} . / \mathrm{km}^{2}$ in the 2014 sampling campaign (Refoyo et al., 2014). The increase in the density of ungulates in certain areas results in an increase in the population of hosts available for parasites and the possible appearance of highly parasitized animals. These, because they have a lower capacity to compete for resources, move to areas where food is scarce causing the alteration of the host habits and even their disappearance which leads the parasite to look for new hosts to which it is not adapted and that, as a consequence, the risk of contagion and the appearance of epizootics increase (Díez-Baños and Hidalgo-Argüello, 2006; Granados et al., 2007).

Regarding the comparison made between different sedimentation methodologies in the study of coprological samples, it should be noted that no significant differences were found for any of the variables studied. These data coincide with those obtained 
by Anécimo et al. (2012) for human faeces in which they did not find relevant differences of detection neither for different groups of protozoa nor for helminths.

Ritchie technique is a methodology routinely used in laboratories because it isolates a wide variety of parasitic forms of faeces, both in fresh and preserved samples and in addition, it is a very sensitive technique to detect mild infections (Funk et al., 2013). However, the use of formaldehyde and ether solvents makes the manipulation of the samples dangerous for operators and attempts to modify the original methodology to reduce or prevent risks in the laboratory.

Under this premise, Barba (2015) compared two techniques used in human coprology with the Ritchie technique to adapt them to routine work with ruminant samples. Their most outstanding results indicate that the use of a commercial kit (Mini Parasep SF®) which does not need solvents and uses two filters of different mesh, shows results very similar to Ritchie technique when it comes to studying the parasitic diversity and therefore, this should be the technique of choice for conducting this type of study since it offers minimal manipulation, shorter processing time, lower cost and decreases the analyst risk of work. These results also coincide with those obtained by Tenorio-Abreu et al. (2013) for human faeces. However, Saez et al. (2011) warns of the use of this kit can cause false negatives since parasitic forms of smaller size can be lost in the manipulation of the sample or stay in the filters that collapse.

The technique used in this work offers consistent results. It is even more economical and as not uses filters, the sample collapse is avoided and for that, probability of detection increases. Samples analyzed with the Anécimo technique show a greater clarity what facilitates parasitic forms to be better detected, something that does not happen with the Ritchie technique in which a greater amount of dispersed organic matter is observed, as pointed out by Barba (2015) in their comparison between techniques.

\section{CONCLUSIONS}

As the main conclusions of this study, we can indicate that although there has not been a sanitary deterioration of the Iberian ibex population under study, a considerable increase has been detected in the prevalence data of the species found with respect to previous works. However, we have found a decrease in the diversity of species that affect the population although a new species of nematode, typical of cattle, has been identified. These facts seem to be related the significant increase in the density of ibex in the area and can support the hypothesis, sustained by other authors, of the exchange of parasites between the populations of wild ungulates and domestic livestock.

On the other hand, the results obtained in this work seem to indicate that the Anécimo technique can be used with guarantees for the study of intestinal parasites in ungulates, since no significant differences have been observed with the technique used as a reference in this type of studies. The improvement in the working conditions of the analysts by not using dangerous solvents to health can be a start to change the protocol of action. However, new studies with other ungulates and a greater number of samples will be necessary for this to be chosen as a reference technique. 


\section{REFERENCES}

ACEVEDO, P.; VICENTE, J.; ALZAGA, $\mathrm{V}$. et al. Relationship between bronchopulmonary nematode larvae and relative abundances of Spanish ibex (Capra pyrenaica hispanica) from Castilla-La Mancha, Spain. Journal of Helminthology, vol.79, n.2, p. 113-118, 2005.

ACEVEDO, P.; SANTOS, J.P.; REAL, R. et al. Evaluación del estado de la población de cabra montés de los montes de Toledo: relaciones con el ciervo. Pirineos. Revista de Ecología de Montaña, vol.166, p. 29-49, 2011.

ALADOS, C. L.; ESCÓS, J. Cabra montés - Capra pyrenaica Schinz, 1838. En: Enciclopedia Virtual de los Vertebrados Españoles. Salvador, A., Cassinello, J. (Eds.). Museo Nacional de Ciencias Naturales, Madrid. 2012. Available:

http://www.vertebradosibericos.org/mam iferos/cappyr.html. Access: 12/11/2019

ALASAAD, S.; GRANADOS, J. E.; CANO-MANUEL, $F$. J. et al. Epidemiology of fasciolosis affecting Iberian ibex (Capra pyrenaica) in southern Spain. Parasitology Research, v.102, n.4, p. 751-755, 2008.

ANÉCIMO, S. R.; TONANI, K. A.A.; FREGONESI, M.B. et al. 2012. Adaptation of Ritchie's Method for Parasites Diagnosing with Minimization of Chemical Products, Interdisciplinary Perspectives on Infectious Diseases, v. 2012, Article ID 409757, 2012. Available:

https://www.hindawi.com/journals/ipid/20 12/409757/cta/ Access: 12/11/2019

AUDESIRK, T; AUDESIRK, G; BYERS, B. E. Biología: la vida en la Tierra. México: Pearson, 2008. p. 970.

AYRES, R. M.; MARA, D. D. Análisis de aguas residuales para uso en agricultura: Manual de técnicas parasitológicas y bacteriológicas.
Ginebra, Suiza: Organización Mundial de la Salud, 1997. p. 31.

BALMORI, A.; RICO, M.; NAVES, J. et al. Contribución al estudio de los endoparásitos del lobo en la Península Ibérica: una investigación coprológica. Galemys, v.12 (nespecial). p. 26, 2000.

BARASONA, A. Epidemiología y prevención en la interacción sanitaria entre ungulados domésticos y silvestres. 2015. Ciudad Real, p. 280. Tesis doctoral. Instituto de investigación en recursos cinegéticos (IREC). Universidad de Castilla-La Mancha.

BARBA, M. Análisis comparado de metodologías de detección por concentración de parásitos intestinales en cabra montés (Capra pyrenaica). 2015. Madrid, p. 75. Tesina de licenciatura. Departamento de Zoología y Antropología Física, Facultad de Ciencias Biológicas, Universidad Complutense de Madrid.

BARBOSA, A. S.; BASTOS, O. M.; UCHÔA, C. M. et al. Comparison of five parasitological techniques for laboratory diagnosis of Balantidium coli cysts. Revista Brasileira de Parasitologia Veterinária, v. 25 , n. 3 , p. 286-292, 2016.

BELTRÁN, M.; TELLO, R.; NÁQUIRA, C. Manual de procedimientos de laboratorio para el diagnóstico de los parásitos intestinales del hombre. Lima: Ministerio de Salud, Instituto Nacional de Salud, 2003. p. 90.

BELTRÁN-SAAVEDRA, L. F.; ANGULO, S.; GONZALES, J. L. Uso de metodologías de censos muestrales indirectos de fecas para evaluar endoparásitos en mamíferos silvestres: Un ensayo en la Reserva Privada de San Miguelito, Santa Cruz, Bolivia. Ecología en Bolivia, v. 44, p. 56-61, 2009.

BODY, G.; FERTÉ, H.; GAILLARD, J. et al. Population density and phenotypic 
Comparison of two parasitological techniques for the diagnosis of intestinal parasites in a population of 43 Iberian ibex (Capra pyrenaica Schinz, 1838) in the Sierra de Guadarrama National Park (Spain)

attributes influence the level of nematode parasitism in roe deer. Oecología, v. 167, p. 635-646, 2011.

CANO-MANUEL, F. J.; GRANADOS, J. E.; ASPIZUA, R. et al. Cambio global y cabra montés (Capra pyrenaica) en Sierra Nevada, España. Galemys, v. 22, p. 433-445, 2010.

CARVALHO, X. L. G.; MOREIRA, E. L.; PENA, L. J. et al. A Comparative study of the TF-Test $₫$, Kato-Katz, HoffmanPons-Janer, Willis and BaermannMoraes Coprologic methods for the detection of human parasitosis. Memórias do Instituto Oswaldo Cruz, v. 107, n. 1, p. 80-84, 2012.

CHAPMAN, H. D.; BARTA, J.R.; BLAKE, D. et al. A selective review of advances in coccidiosis research. Advances in Parasitology, v. 83, p. 93171, 2013.

CORDERO DEL CAMPILLO, M.; ROJO VÁZQUEZ, F. A. (Coords.). Parasitología Veterinaria, Madrid: Mc Graw Hill Interamerica, 2000. p. 968.

DEL COCO, V. F.; CÓRDOBA, M. A.; BASUALDO, J. Comparación de tres técnicas de concentración de heces para recuperar ooquistes de Cryptosporidium. Acta Bioquímica Clínica Latinoamericana, v. 42, p. 333337, 2008.

DIEZ-BAÑOS, N.; HIDALGOARGÜELLO M. R. Análisis del estado parasitario de rumiantes silvestres en el norte de Castilla y León. Mesa Redonda. In: Veinte años de buiatría. (Mesa Redonda). 14 CONGRESO INTERNACIONAL DE LA FEDERACIÓN MEDITERRÁNEA DE SANIDAD Y PRODUCCIÓN DE RUMIANTES (Fe.Me.S.P.Rum), LugoSantiago de Compostela, 2006, p. 95102.

FERNÁNDEZ DE MERA, I. G. Factores
implicados en la respuesta inmunitaria en el ciervo ibérico. 2007. Ciudad Real. p. 202. Tesis doctoral. Departamento de Ciencia y Tecnología Agroforestal y Genética e Instituto de Investigación en Recursos Cinegéticos (IREC), Unidad de Sanidad Animal, Universidad de Castilla-La Mancha.

FUNK, A. L.; BOISSON, S.; CLASEN, T. et al. Comparison of Kato-Katz, EthylAcetate Sedimentation, and Midi Parasep in the Diagnosis of Hookworm, Ascaris and Trichuris infections in the context of an evaluation of rural sanitation in India. Acta Tropica, v. 126, n. 3, p. 265-268, 2013.

GRANADOS, J. E.; FANDOS, P.; SERRANO, E.; et al. Bases para la implementación de un plan de gestión de la cabra montés en Andalucía. In: Biodiversidad y Conservación de Fauna y Flora en Ambientes Mediterráneos. Granada: Sociedad Granatense de Historia Natural Editors: J.M. Barea-Azcón, M. Moleón, R. Travesí, D. Ballesteros-Duperón, J.M. Luzón-Ortega, J.M. Tierno de Figueroa, 2007, cap. 24, p. 669-690.

HATCHER, J. M.; DUNN, M. A. Parasites in Ecological Communities from Interactions to Ecosystems, Cambridge: Cambridge University Press, 2011, p. 445.

HERNÁNDEZ, H. M.; GARCÍA ALDRETE, A. N.; ÁlVAREZ, F. et al. 2001. Enfoques contemporáneos para el estudio de la biodiversidad. 1 ed. México: Instituto de Biología. Universidad Nacional Autónoma de México. Fondo de Cultura Económica, 2001, p. 420.

HUDSON, P. J.; DOBSON, A. P.; LAFFERTY, $K$. D. Is a healthy ecosystem one that is rich in parasites? Trends in Ecology and Evolution, v. 21, p. 381-385, 2006.

INDRE, D.; DARABUS, G. H.; OPRESCU, I. and MORARIU, S. et al. 
Morphometrical studies on some eggs of gastrointestinal nematodes from sheep. Lucrări Ştiinłifice Medicină Veterinară, v. 43, p. 30-35, 2010.

JOLY, D.; MESSIER, F. The effect of bovine tuberculosis and brucellosis on reproduction and survival of wood bison in Wood Buffalo National Park. Journal of Animal Ecology, v. 74, n. 3, p. 543551, 2005.

KARIM, W.; FARAJALLAH, A.; SURYOBROTO, B. Exploration and prevalence of gastrointestinal worm in buffalo from West Java, Central Java, East Java and Lombok, Indonesia. Aceh Journal of Animal Science, v. 1, n. 1, p. 1-15, 2016.

KAUFMANN, J. Parasitic infections of domestic animals: a diagnostic manual. Springer Basel AG., 1996, p. 423.

MARZAL, A.; DE LOPE, F.; NAVARRO, C.; MOLLER, A. P. et al. Malarial parasites decrease reproductive success: an experimental study in a passerine bird. Oecologia, v. 142, p. 541- 554, 2005.

MCNABB, S. J. N.; HENSEL, D. M.; WELCH, D. F. et al. Comparison of sedimentation and flotation techniques for identification of Cryptosporidium sp. oocysts in a large outbreak of human diarrhea. Journal of Clinical Microbiology, v. 22, p. 587-589, 1985.

PÉREZ JIMÉNEZ, J. Distribución, genética, y estatus sanitario de las poblaciones andaluzas de la cabra montés. Jaén: Universidad de Jaén, Consejería de Medio Ambiente. 2001, p. 276.

QUIROZ, H. Parasitología y enfermedades parasitarias de animales domésticos. México: Limusa. 2005, p. 870.

RAMAJO, M. V.; PÉREZ, R.; RAMAJO, H. A. et al. Preliminary data about the parasitism caused by Protozoa,
Helminths and Ticks in cervids and wild bovids from Salamanca (western Spain). Research and Reviews in Parasitology, v. 67: p. 69-77, 2007.

REFOYO, P. La cabra montesa (Capra pyrenaica victoriae) en el Parque Regional de la cuenca alta del Manzanares (Sierra de Guadarrama). Proceso de reintroducción, parasitosis y modelización del nicho ecológico a nivel regional y peninsular. 2012. Madrid. p. 330. Tesis doctoral. Universidad Complutense de Madrid, Facultad de Ciencias Biológicas, Departamento de Zoología y Antropología física.

REFOYO, P.; OLMEDO, C.; POLO, I. et al. Demographic trends of a reintroduced Iberian lbex population (Capra pyrenaica victoriae) in central Spain. Mammalia, v. 79 , p. 139-145, 2014.

REFOYO, P.; OLMEDO, C.; BARBA, M. et al. Parasite load in the Iberian ibex, Capra pyrenaica victoriae. Arxius de Miscel-lània Zoològica, v. 14, p. 108113, 2016.

RITCHIE, L. S. An ether sedimentation technique for routine stool examinations. The Bulletin of the U.S. Army Medical Department, v. 8, n. 4, p.326, 1948.

RUIZ, A.; GONZÁLEZ, J. F.; RODRÍGUEZ, $E$. et al. Influence of climatic and management factors on Eimeria infections in goats from semiarid zones. Journal of Veterinary Medicine (Series B: Infectious Diseases and Veterinary Public Health), v. 53, p. 399-402, 2006.

SAEZ, A.; MANSER, M.; ANDREWS, N. et al. Comparison between the Midi Parasep and Midi Parasep Solvent Free (SF) faecal parasite concentrators. Journal of Clinical Pathology, v. 64, p.901- 904, 2012.

SALVATELLA, R.; EIRALE, C. Examen coproparasitario. Metodología y empleo. 
Revisión técnico metodológica. Revista Médica de Uruguay, v. 12, p. 215-223, 1996.

SMITH, V.; JONES, T.; SMITH, M. Host nutrition and infectious disease: an ecological view. Frontiers in Ecology and the environment, v. 3 , n.5, p. 268274, 2005.

TENORIO-ABREU A.; GIL-TOMÁS, J. J.; MARTÍNEZ-MACÍAS, O. et al. Comparación entre 2 técnicas de concentración de parásitos (Copropack versus Mini Parasep Solvent Free). Enfermedades Infecciosas y Microbiología Clínica, v. 31, n. 5, p. 347- 352, 2013.

TOMPKINS D. M.; DUNN A. M.; SMITH $M$. J. et al. Wildlife diseases: from individuals to ecosystems. Journal of Animal Ecology, v. 80, p.19-38, 2011.

VAN WYK, J. A.; CABARET, J.; MICHAEL, L. M. 2003. Morphological identification of nematode larvae of small ruminants and cattle simplified. Veterinary Parasitology, v. 119, p. 277-306, 2003.

VAN WYK, J. A.; MAYHEW, E. Morphological identification of parasitic nematode infective larvae of small ruminants and cattle: A practical lab guide. Onderstepoort Journal of Veterinary Research, v. 80, n. 1, Art. \#539, $2013 \quad$ Available: https://ojvr.org/index.php/ojvr/article/view I539 Access: 12/11/2019.

WISNIVESKY, C. Ecología y epidemiología de las infecciones parasitarias. Costa Rica: Editorial Libro Universitario Regional, 2003, p. 398.

YANG, R.; BRICE, B.; ELLOIT, A. et al. Morphological and molecular characterization of Eimeria paludosa coccidian parasite (Apicomplexa: Eimeriidae) in a dusky moorhen (Gallinula tenebrosa, Gould, 1846) in
Australia. Experimental Parasitology, v. 147, p. 16-22, 2014. 